\title{
Analyzing the Fragmented Sri Lankan Muslim Politics in Post-Ashraff Era
}

\author{
Mohammad Agus Yusoff ${ }^{1}$, Athambawa Sarjoon ${ }^{2} \&$ Zawiyah Mohd Zain ${ }^{3}$ \\ 1 History, Politics and Security Research Center, Faculty of Social Sciences and Humanities, Universiti \\ Kebangsaan Malaysia, UKM Bangi 43600, Selangor, Malaysia \\ ${ }^{2}$ Department of Political Science, Faculty of Arts, University of Peradeniya, Peradeniya 20400, Sri Lanka \\ ${ }^{3}$ Collage of Law, Government and International Studies, Universiti Utara Malaysia, UUM Sintok 06010, Kedah, \\ Malaysia
}

Correspondence: Athambawa Sarjoon, Department of Political Science, Faculty of Arts, University of Peradeniya, Peradeniya 20400, Sri Lanka. Tele: 94-7-7308-0654. E-mail: sarjoona@gmail.com; sarjoona@pdn.ac.lk

Received: April 26, $2018 \quad$ Accepted: June 17, $2018 \quad$ Online Published: August 12, 2018

doi:10.5539/jpl.v11n3p17 URL: https://doi.org/10.5539/jpl.v11n3p17

\begin{abstract}
The traditional Muslim politics in Sri Lanka transformed with the formation of Sri Lanka Muslim Congress (SLMC) and its active communal politics under its founder-leader, M.H.M.Ashraff. While representing the interests of the Muslim community, particularly those living in the north-eastern region, SLMC through its politics of bargaining and consensus voiced and advocated for the interests, rights and privileges of the Muslim community as well as contributed to their socio-economic and cultural upliftment at the crossroad of ethnic conflict and civil war. Although SLMC received popular mandate from the Muslim community, the party fell into fragmentation with the unexpected demise of its founder-leader in 2000, and splits were instigated shortly. This fragmentation caused a severe effect in the distinct path of Muslim politics in Sri Lanka. This study examines the fragmented nature and the trends of Muslim politics, particularly the politics of SLMC in post-Ashraff era and their impact. This study reveals that the fragmentation within SLMC caused leadership crisis and emergence of many Muslim political parties that promoted ugly politics of opportunism. This trend ultimately reduced the bargaining strength of Muslim politics, negatively influenced representative politics, leading to the negligence and marginalisation of Muslims' concerns and grievances in national politics. The leadership crisis and regionalism also negatively influenced the politics of SLMC and other Muslim parties in post-Ashraff era. This study also finds that unifying splinter-groups, reforming party structure and procedures, and redefining goals and path of achieving them would not only strengthen the politics of SLMC and other Muslim political parties but also would give a new brand for Muslim minority politics in Sri Lanka.
\end{abstract}

Keywords: Sri Lanka, Muslim politics, Sri Lanka Muslim Congress, post-Ashraff era, fragmentation

\section{Introduction}

Traditionally, the Muslim community in Sri Lanka has been involved in politics by aligning with the two major ethnic groups, the Sinhalese and the Tamils, hoping that such alignment can help save and empower their community. This pragmatic view of politics discouraged them to form political parties to represent their own community interests. The formation of a strong Muslim political party, Sri Lanka Muslim Congress (SLMC) in the mid-1980s was successful partly due to the intense ethnic conflict as well as negligence and marginalisation of Muslims' interests by the leaders of ethnic majority and their political parties (Yusoff, Sarjoon, Hussin \& Ahmed, 2017). The SLMC grew as a strong political voice and representative institution of the Muslim community with the utmost support of the Muslims, particularly those living in the war-torn north-eastern Sri Lanka.

The emergence of SLMC as a Muslim party based on Islamic faith and fundamentals influenced Muslim and national politics. This phenomenon also contributed to the dynamic changes in the traditional setups of Muslim politics in Sri Lanka. The politics of SLMC turned the Muslim community into the 'king-making' or 'queen-making' community in national politics. When SLMC became a coalition partner in the national 
government, the party advocated for the rights and privileges of Muslim community and worked towards promoting their socio-cultural and economic conditions. As a result, the politics of SLMC was viewed as Muslim politics in Sri Lanka. The founder-leader of the SLMC, M.H.M.Ashraff, played a decisive role in all the successes of the SLMC and Muslim politics.

However, SLMC progressively lost its pride and became fragmented after the unexpected demise of its founder-leader in a helicopter clash in October 2000. This event further induced splits within SLMC and promoted the formation of new Muslim political parties. In post-Ashraff era, the politics of SLMC and the Muslim politics of Sri Lanka faced many challenges with splits and ups and downs. SLMC and other Muslim political parties succeeded in representative politics, but the distinctive identity of Muslim parties and their bargaining strength considerably declined in post-Ashraff era. Given the severe leadership crisis and promotion of regionalism in SLMC and other Muslim parties, Muslim politics could not achieve any notable success in post-Ashraff era. The assurance of rights and privileges of Muslims in politico-economic spheres, their equal status and participation in peace negotiation and political settlement, further progress of socio-economic conditions of the Muslim community and their areas as well as the assurance for promoting and practicing their ethno-religious identity and norms were highly questioned in post Ashraff era.

All these negative developments induced an academic investigation of why Muslim politics in post-Ashraff era became fragmented and lost its pride in national politics. Shifts and reforms in the politics of other ethnic groups in the recent past occurred to represent their community and voice their community interests and grievances, but no such development was noticed within the politics of SLMC and the other Muslim parties. In this study, we examine why SLMC, once treated as a mother party to distinct Muslim politics, became fragmented and lost its pride in Muslim and national politics and how these factors influenced the Muslim minority politics in Sri Lanka. This study pays critical attention on the cleavages within SLMC and other Muslim parties in post-Ashraff era and their impact on the politics of SLMC and Muslim minority in Sri Lanka.

\section{Methodology}

This research is a critical study based on interpretive analysis. Information and data gathered from desk analysis and field survey (interviews) are used for and against the arguments developed in this study. Primary sources are collected mainly from interviews conducted among individuals selected through random sampling among politicians, civil actors, educationists, journalists and public. In this paper, however, individual opinions are summarised and presented under thematic topics and arguments without exposing personal information (e.g. names). Secondary data and information are collected from literary books, journal articles and online sources. These sources record the history of Muslim politics and its changing dynamic and issues in post-Ashraff era. This study uses data and information collected from these sources as quotations, quotations of others, summaries and interpretive arguments together with the extensive description of political events and backgrounds.

With the formation of SLMC and its active participation in national politics and advocacy for the Muslim community, the politics of SLMC was viewed and labelled as Muslim politics in Sri Lanka. In post Ashraff era, SLMC continued to be influential and dominated Muslim politics, although many Muslim parties were forming and functioning at the national level. Our study examines the nature, fragmentation and political trends of SLMC in post-Ashraff era specifically and the fragmented politics of other parties and their impact on Muslim politics in general.

\section{Traditional Muslim Politics and the Influence of SLMC in Sri Lanka}

The traditional Muslim politics in Sri Lanka was not ideologically formed, but it was always neutral and supportive of two major ethnic groups in the country, the Sinhalese and the Tamils. The first generation of Muslims leaders started their politics with pro-Sinhalese or pro-Tamil parties. Muslims' support or alliance with Sinhalese parties is notable because it continues up to now in Sinhalese-predominant areas even with the presence of Muslim parties. Early Muslim leaders realised that unless they aligned themselves politically with the Sinhalese elites, the prospect of prosperity and peace for Muslims in the country would be seriously jeopardised (Ali, 2013). Therefore, most Muslim leaders were trustworthy to major Sinhalese parties and the governments they formed. This pragmatic view of politics also discouraged them to form political parties of their own for exclusively representing the interests of Muslims. Therefore, no clear ideology politics was found among the early generation of Muslim leaders, and most of them focused on electoral success to safeguard the community. This kind of pragmatism helped these Muslim leaders, with few exception, always be aligned with the government's side, although they were elected on the opposition wings.

Such brand of Muslim politics was criticised by ethnic majorities as opportunistic, but Muslim leaders justified it as for the sake of community development and interests. Muslims had opportunities for political bargaining 
which they used to the great advantage of their community. Ruling parties also welcomed the Muslims into their fold to showcase to the world that their policies and programmes were non-discriminatory towards minorities (Ali, 2013). Such tradition of Muslim politics benefited the Muslim community, but Muslim leaders were always under the control of ruling parties which limited the expression of their opinion on occasions that negatively influenced the interests of Muslim community. When policies and projects of these parties disproportionately victimised the Muslim community and openly challenged the interest of Muslims in the country, Muslim leaders on the government side could not oppose those governments' interests. It is worth noting that President Jayawardena (1978-1989) openly challenged his Muslim parliamentary colleagues to quit the government if they opposed his foreign policy (Cader, 1999).

The position and strategies of pro-Sinhalese political parties and governments continued to oppose the interests of Muslims. The politics of Tamils also failed to accommodate Muslim interests in the peak of ethnic conflict and civil war. This vulnerable position of Muslims induced several civil activists and intellectuals to establish a Muslim political party, resulting in the establishment of SLMC. The SLMC was initially formed as a social welfare organisation on 11 September 1981 under the patronage of Ahamed Lebbe, the chairman of Kattankudy Urban Council (Sarjoon, 2001). Delegates at the inaugural meeting gave M.H.M. Ashraff the leadership of the organisation. Ashraff was a political activist and an advocate (lawyer) who was closely associating with the Tamils United Liberation Front (TULF) and Muslim United Liberation Front (MULF) during the 1970s. He also advocated for the separate state for Tamils in north-eastern Sri Lanka (See Yusoff et al., 2017; Jeyaraj, 2016).

The intense ethnic conflict and civil war activated the district Muslim political movement under SLMC. The SLMC was officially declared as a political party in 1986 and became a registered political party in 1988, only few months before the provincial council elections. Since 1986, SLMC had been advocating for the rights and privileges of the Muslim community knocked by the impact of ethnic conflict and civil war. The Muslim community, particularly Muslim youngsters, were frustrated and ready to mobilise for armed struggle because of the impact of violent conflict and marginalisation of their interests by the government authorities and major ethnic groups. This pathetic context pushed Ashraff to organise protest demonstrations over the issues affecting Muslims. He turned the attention of Muslim youngsters towards the democratic path of politics during the peak of ethnic conflict and violent civil war in Sri Lanka (Yusoff et al., 2017).

The emergence of SLMC was a timely action of Ashraff to protect the Muslim community, especially the youngsters, from turning to violence and terrorism or taking up arms to protect them from targeting of armed rebel forces and the marginalization of Muslims by the political leaders. The formation of SLMC resulted in promoting an ethno-religious identity and orientation for Muslim politics. Similarly, Ashraff turned Muslim politics into mass (public) politics that seriously focused on poor voters and their socio-economic wellbeing. Ashraff advocated for the grievances of the middle class and ordinary public and worked for improving their socio-economic conditions (See Yusoff et al., 2017; Sarjoon, 2001).

Electoral victories in successive elections at local, provincial and national levels strengthened the SLMC's representative politics and bargaining power for the sake of its community. As a result, SLMC became the 'queen-maker' in national politics for the first time after the 1994 general election when it received seven members in the national parliament, the decisive number necessitated to form government. The anti-Muslim stance of Liberation Tigers of Tamil Eelam (LTTE) in the north-east and the anti-UNP sentiment at the national level signalled for regime change and for the electoral success of SLMC, and the People's Alliance (PA). SLMC became a coalition partner of PA in 1994 for the first time.

\section{Demise of Ashraff and Leadership Crisis Within SLMC}

Ashraff was keen in protecting and preserving the dignity of SLMC's leadership in his hand. Whenever he faced challenges to his leadership, he succeeded in removing the personalities from the party, expecting to avoid divisions or splits within the party. Ashraff extended his control on all aspects of party affairs. However, his sudden demise imposed a number of splits and divisions within the SLMC. Ashraff had not proposed or openly promoted his successor within the party structure, although the party has a bureaucratic structure. He functioned as a supreme national leader, but no one or no forum existed to discuss about its negative impact. His absence encouraged many second-level leaders to fight for the party's leadership. In addition, many were promoting personalities, such as the party's secretary general, senior deputy leaders and the widow of Ashraff, to take the party leadership. This event ultimately resulted in promoting two wings within the party under two personalities for leadership: one group promoted Ferial Ashraff, widow of late Ashraff whilst she was performing religious practice for her late husband, and the others promoted Rauff Hakeem, the party's secretary general. After lengthy discussions, agreement reached to have both as co-leaders of the party. An issue of 'east' and 'south' in deciding 
the leadership for the party also existed. Seeing that Ashraff emerged from a village in the eastern province and the party has a voter bank in the north-eastern region, specifically in the eastern province, many stalwarts advocated for the east-based leadership.

In post-Ashraff leadership revelry, however, the south influenced and controlled the whole party which was negatively reacted by north-eastern leaders and party loyalties. SLMC hailed from the eastern province and mostly supported by north-eastern Muslims. It received several criticisms and few supports from southern Muslims. However, SLMC grew and influenced Muslims and national politics with the upmost support of Muslims in the north-eastern region. SLMC was once viewed as a general Muslim politics in Sri Lanka. Given that SLMC's political base was in the east, most eastern members in the politburo and party stalwarts urged that the leadership of SLMC after the demise of Ashraff should go to eastern province. However, SLMC leadership went to Rauff Hakeem, a member (not a founding-member) from the south (Kandy) within a short period.

Hakeem is from the central province and technically not a 'Kizhakku Mannin Mainthan' (son of eastern soil) which caused continued east-south leadership rift within the party. Later, such rift paved way for the emergence of many groups and parties from SLMC. Many SLMC members and those who left SLMC and formed other parties continued to argue that the leadership of SLMC should be given to a member of the eastern province. Eastern Muslims traditionally neglected the southern Muslim personalities and their representatives and leaders even before SLMC was formed and began to influence the national politics. The defeat of popular southern Muslim leader, Dr. Badiuddin Mahmood in the 1977 election in Batticaloa district clearly justified it. Therefore, when a southern member became the leader of SLMC, eastern members negatively reacted. Family background has been more of a liability than a political resource for Hakeem, in particular, because he was seeking to attract Muslim voters from all regions of the island, including the east. The Kandyan issue was also used negatively by certain eastern-born rivals who undermine Hakeem's leadership. This compelled Hakeem to contest from Amparai district rather than from his home district of Kandy in 2004 parliamentary election (McGilvray \& Raheem, 2007).

\section{Nature and Trends of Muslim Politics on the Fragmentation of SLMC}

The fragmentation of SLMC influenced the nature and trend of Muslim politics in post-Ashraff era in different ways. This event allowed for the formation of few more Muslim political parties and their ugly politics. The fragmentation also resulted in questioning Muslim leadership and political representation and collective voice towards Muslims' concerns and grievances. The increased clash of divisions within party loyalists further induced splits and fragmentation within all Muslim parties. Ultimately, fragmentation and opposition politics of Muslim parties seriously challenged the identity and strength of Muslim politics at regional and national levels that were proved and maintained by Ashraff through his brand of distinct Muslim politics in Sri Lanka. The following sub-sections extensively examine the nature and trends of Muslim politics on the fragmentation of SLMC in post-Ashraff era.

\subsection{Emergence of Minor Parties Within Muslim Politics and Their Ugly Politics}

The demise of Ashraff and fragmentation within his party induced formation of many small parties among Muslims. Among them, certain parties had been influential in regional and national politics, but many could only sign at a local level. Immediately after the demise of Ashraff, SLMC became split into two wings when two personalities were named for the party's co-leadership. However, co-leadership did not exist for more than six months. These two groups fought over the interest of achieving the national leadership. This incident prompted them to search legal advice to decide the party's leadership. Since there were parliamentarians from SLMC and its new child-party, National Unity Alliance (NUA), thus, agreement reached to separately lead SLMC and NUA by Hakeem and Ferial Ashraff respectively. However, Ferial Ashraff began to separate her party's affiliations with SLMC, and she progressively supported the People's Alliance led by President Chandrika Kumaratunga without any conditions. From its inception, NUA has always contested elections as part of the People's Alliance coalition centred around the Sri Lanka Freedom Party (SLFP), and SLMC mostly preferred to be aligned with and contested the election as part of United National Front (UNF) coalition centred around the UNP. Thus, the level of independent popular Muslim support for SLMC was unclear. However, a woman taking on the leadership of a Muslim party and remaining in that position in the face of Muslim political factionalism was evidently noteworthy, especially because negative gender issues were raised by SLMC partisans at critical points to undermine Ferial Ashraff's legitimacy (McGilvray \& Raheem, 2007).

In 2002, another inner-party division occurred within SLMC. Its chairman A.L.M.Athaullah who was also one of the Amparai district parliamentarians, led a revolt of sorts when Hakeem was away from the country to participate at the peace talks with LTTE as a member of government delegates in Oslo, Norway. Athaullah and the party's 
General Secretary Dr. A.L.M.Hafrath summoned the politburo of SLMC for a constitutional coup and to sack Hakeem from the party's national leadership (See: Bustø, 2007; Jeyaraj, 2004). A clash occurred between Hakeem and Athalullah over Hakeem's leadership and his monopolisation of cabinet ministerial position given to the party. Hakeem returned from Oslo in a hurry to cope with the crisis. He suspended Athaullah and some others from the party which ultimately prompted Athaullah and his supporters to leave SLMC. In February 2003, Athaullah and his supporters formed the Ashraff Congress to compete with SLMC. One year later, they changed the party's name to National Muslim Congress and to National Congress (NC) in 2005. The NC has always been opposed to the leadership and politics of SLMC. In the middle of 2004, another group under Mussammil and Hafiz Nasser Ahamed, the Director of International Affairs Division of SLMC during Ashraff period left SLMC and formed another Muslim party called Democratic Unity Alliance (DUA), and they claimed that the party would protect and continue the vision and mission of Ashraff which promoted national unity and peace in the country (Gunatilleke, 2004).

Regardless of the factors related to Ferial Ashraff and Athaullah, SLMC under Rauf Hakeem once again fared best among Muslim parties at the 2004 polls. The party had 10 seats, but fragmentation began again on the leadership of SLMC and its decisions. A group of three led by Rishad Bathiudeen broke away the party, questioning the leadership of Hakeem in May 2004 and joined the government of Chandrika Kumaratunga. The group included Najeeb A. Majeed and Ameer Ali. Shortly, they were expelled from SLMC (TamilNet, 2004). As a result, the dissident SLMC members of parliaments (MPs) founded a new political party, the All Ceylon Muslim Congress later in 2005. However, they changed the party name to All Ceylon Makkal Congress (ACMC) later. A potential second split was noticed among the remaining six SLMC members after Mahinda Rajapakse became president in 2005. Three of the six, namely, Faisal Cassim, S.Nijamudeen and K.A.Baiz wanted to break away and join the government. In a bid to prevent the party from breaking up again, however, SLMC took a policy decision and joined the government together as a coalition party.

At present, more than six parties represent few and scattered Sri Lankan Muslims with other major parties. All of them advocate that they follow the path of SLMC's founder, Ashraff. However, a bipolar division on the political alliance of Muslim parties is evident-some are aligned with the UNF and others with the UPFA. In their political process, the in-fighting within and between each Muslim party slowly worsens. Criticising leaders of other parties, revealing personal matters of leaders and making thunderous speeches were few of the worst forms of activities that the major and regional leaders of these parties do. Moreover, regionalism plays a major role in all parties in attracting local voters. Muslims are now divided by their party affiliations, regional biases and on personal grounds. Offensive, filthy and vulgar languages are limitless in election campaign meetings. During elections, campaigns target even chasing out Muslim politicians or leaders from other regions or districts campaigning for their candidates. Character assassinations of the opposite party candidates occur every meeting. Ugly inter-and intra-party rivalry among Muslim candidates gradually worsen (Siddeek, 2015a).

Many of the Muslim parties consist of disgruntled MPs who were opposed to SLMC leadership, but they seldom coalesce even as a loose Muslim opposition alliance. Each party secures the best deal it can get from the government in power and uses its leverage to negotiate deals for personal power and patronage in a manner reminiscent of the switchover politics of Muslim politicians in the 1950s and 1960s (McGilvray \& Raheem, 2007). In post-Ashraff era, the SLMC leaders allowed many newcomers and appointed them to the higher positions in the party's structure. These newcomers were in opposition wings to SLMC and mostly criticised SLMC's founder-leader and its district politics. Naseer Ahamed and Azad Sali were some of them who really challenged the politics of SLMC and its leadership. Many traditional loyalties were not given opportunity to contest in elections at least at local level. This reduced the popular support to the party during elections and gradually brought criticisms and oppositions.

SLMC has a tradition of opposing money and elitist or feudalist politics until Ashraff was leading the party. SLMC was labelled as a party for ordinary mass and anyone can be involved in its politics. However, it became a party of powerful and wealthy individuals in post-Ashraff era. In addition, it became obvious tradition that any newcomer or only wealthy ones could contest the elections under SLMC. Recent electoral victories of Muslim parties, including SLMC were highly decided by extending wealth and influence within the party structure instead of political knowledge or by their policies and plans for Muslim community. Many cases and petitions failed against Muslim leaders claiming that they were involved in corruption and money dealing for coalition making with major parties from regional to central levels, as well as in the business of their ministries. Many of those who left SLMC opposing the leadership revealed that SLMC leaders mostly bargained for money and positions instead of insuring community rights and interests. 


\subsection{No Strong Ideological Stand}

The selfish politics of SLMC and more than half a dozen splinter groups or parties brought nothing but disaster to the Muslim community and its polity. No strong policy and decision was found among Muslim parties on matters influencing the lives and livelihoods, ethnicity, religion and culture, rights and privileges of the Muslim community. No party has a strong policy on supporting major political parties at national and provincial levels. Sri Lanka has two major parties that function on two different ideological bases, that is, UNP stands mostly for liberal democracy and SLFP for social democracy. However, many Muslim parties do not stand on concrete political ideological basis. The stand of SLMC's founder-leader before he formed the party favoured socialism. He expressed his stand for socialism through his writings, party's convention resolutions, and public speeches. This stand might have helped him to initially make alliance with the major Tamil party, TULF and the major socialist party among Sinhalese, the SLFP.

Until his demise, Ashraff did not form any direct alliance with the UNP which stands on capitalism. He was a critic of the present UNP leadership and publicly revealed that he would never align with UNP until Ranil Wickramasinghe leads it. After his demise, however, SLMC and its splinter groups easily made alliance with the UNP in a number of occasions though Ashraff's public pronouncement was always remaindered by civil actors. In post-Ashraff era, SLMC favoured to align with the UNP and contested elections under its symbol even in the districts of eastern province which are the major support bases of SLMC. Similarly, no strong policy was found among other Muslim parties in making alliance with UNP or SLFP or coalition parties. This policy of alliance making with national parties was criticised by Muslims and other communities as opportunistic and negatively influenced on the image of Muslim politics in post-Ashraff era.

\subsection{Fragmentation Within All Muslim Parties}

In post-Ashraff era, all Muslim political parties witnessed fragmentation due to leadership rivalry, regionalism and powerful positions. As mentioned earlier, SLMC immediately became split into two major wings, one under the leadership of Rauff Hakeem and the other under the leadership of Mrs. Ferial Ashraff. Frequent splits occurred within SLMC in the following years.

In the recent past, SLMC lost one of its prominent figures, Hasan Ali who earlier acted as party's treasurer and later as party's secretary general for a long period. He was among the two who were instrumental in making of SLMC as a registered and successful Muslim party in electoral politics at provincial and national levels. Hasan Ali was a trustworthy member for SLMC's new leader Rauff Hakeem, too. Therefore, Ali was nominated to parliament three times during post-Ashraff era representing SLMC as a national list Member of Parliament (MP). Many people agree that Ali was the brain of SLMC and its leadership in post-Ashraff era. However, the party's national leadership started marginalising him in the party's affairs when he was seriously advocating SLMC's major demands, particularly the Muslims' autonomy demand, Kalmunai administrative district demand and land related issues of Muslims. Ali also opposed many decisions unanimously taken by the party's national leader violating people's mandate and the agreements reached earlier. Ali claimed that these decisions were earlier taken at the interest of Muslim community. He also argued that Rauff Hakeem does not feel for the eastern Muslims as he is from Kandy (See: Balachandran, 2016). This interest clash induced for permanent division between the party leader and the secretary general. At a point, the party leadership appointed another secretary with monthly pay to look after electoral affairs of the party, making Ali powerless. Ali was unhappy with his powers being clipped by the party leadership despite being the secretary general which resulted in a serious split between Hakeem and Ali wings in the party. Moreover, Ali progressively stayed away from party affairs.

Hasan Ali argues that changes have occurred in the positions of present SLMC from its earliest positions. Ashraff maintained a policy that if the party leadership comes from the north-east, the secretary who is the next powerful position within the party structure, should remain in out of north-east. However, the current leader who is not from the north-east, has taken all the powers with him and reduced the powers of the secretary general, a post which was later abolished. He also left north-east voters in a powerless position. The decision of marginalising Hasan Ali and other prominent figures in the party received huge criticisms to SLMC's leadership. The leaving of several important party loyalties, such as Jameel, SLMC's youth wing leader and chief of SLMC members of Eastern Provincial Council, Basheer Segu Dawood, the long-term chairman of SLMC, Jawath, a founding member and a former member of the Eastern Provincial Council and other local level leaders, such as Thahir and Anzil, both were former Chairmen of local government bodies, in recent years also widened the fragmentation within SLMC.

The clash between Hakeem and Basheer Segu Davood was also notable fragmentation within SLMC in the recent past. Ashraff was impressed by Basheer Segu Dawood who was initially a member of a Tamil rebel group, 
called Eelam Revolutionary Organization of Students (EROS) and a member of parliament from 1989 to 1994 representing EROS. Ashraff appointed Basheer to the party's politburo in 1994. In post-Ashraff era, Basheer had been staunchly loyal and a tower of strength to Hakeem. He also helped Hakeem overcome many critical situations within the party and its coalition politics with Sinhalese parties (Jeyaraj, 2012). This helped him be appointed as a national list parliamentarian by Hakeem though he has been repeatedly rejected by the public in elections. However, predictions spread that Basheer was conspiring to break away from SLMC and accept the cabinet minister post after the Eastern Provincial Council poll in 2012 because he and other SLMC loyalties clashed on the matter of contesting the Provincial Council election under UPFA or SLMC alone (See: Jeyaraj, 2012). Accepting the cabinet post in 2014 whilst Hakeem was abroad and without notifying the party's supreme council also signalled Basheer's breakaway from the party. The clash between Basheer and Hakeem intensified when Hakeem rejected the appeal of Basheer to contest the election under the party list in his constituency at the 2015 general election and to appoint him as a national list parliamentarian. As a result, Basheer left the party and reported number of criticisms against Hakeem's leadership and decisions.

The breakaway of Ali and Basheer, the two prominent figures and major forces in SLMC in post-Ashraff era, influenced further divisions in SLMC that allowed many local level leaders to leave the party. These leaders later formed another Muslim political party called United Peace Alliance (UPA) in 2017. The electoral success of the UPA in the recent local government elections (held in March 2018) witnessed the decline of SLMC's public support in many local government bodies in the eastern province. In the post-Ashraff politics of SLMC, Ali and Basheer were regarded as the right and left hands of Rauf Hakeem, respectively. A remarkable aspect of recent Muslim politics has been the consistent steadfastness of Muslim congress supporters on the one hand and the fickleness of those elected from the party on the other. People remain loyal to the party, but certain elected ones are disloyal to the leadership and by extension to the party. Divisions and fragmentation have been the bane of SLMC in recent times (Jeyaraj, 2012). Other Muslim parties experience the same problems, too.

The splinter groups of SLMC which later formed their own political parties, also faced fragmentation in several occasions. The two popular Muslim political parties, namely, the NC and the ACMC that were formed out of split within the SLMC, have also further fragmented and lost its loyalties in many occasions mainly due to leadership crisis and regionalism within the party. ACMC secured three seats in parliament at the 2010 general election, including the leader of the party, Rishad Bathiudeen, Hunais Farook and M.L.A.M.Hisbullah, but a clash occurred between them. Therefore, Hunais Farook left the party in 2014 and joined UNP. Hisbullah who was a founder-member of SLMC but later left the party opposing the leadership of Hakeem, joined ACMC and was appointed as the party's national organiser (Daily Mirror, 2014). Though he was representing ACMC, he remained in UPFA when ACMC left the UPFA coalition to support the common opposition presidential candidate in December 2014. Hisbullah later joined SLFP. ACMC secured five seats in the parliament after the 2015 general elections, but one more split occurred after the election on the matter of allocating national list MP position. The ACMC general secretary, Y.L.S.Hameed wanted to be appointed as national list MP arguing that his name was included in the list submitted to the election commission. However, ACMC leader, Bathiudeen appointed M.H.M.Navavi from Puttalam district to honour the generous supports rendered by the Puttalam people to the displaced northern Muslims (See: Razak, 2016). This decision caused clash of opinion between Bathiudeen and Hameed, ultimately ending with the sacking of Hameed from the secretary post and appointing a new secretary. This issue brought criticisms to the ACMC leadership because Hameed had been instrumental for many successes of the party in the past.

Similarly, Nnational Congress (NC) leading by Athaullah also faced fragmentation and lost its loyalties in many occasions. When Athaullah left SLMC with some others opposing the leadership of Hakeem and his autocratic role in SLMC, he was regarded as the emerging leader for the Eastern Muslims. Although Athalullah attempted to extend this party and leadership, and able to compete with SLMC to a certain extent, later his party too faced regionalism challenge and leadership crisis. Therefore, for a long period, it was a one-member party in parliament. When he promoted nepotism, some of his popular loyalist such as A.L.Thavam, left the party and succeeded their politics in SLMC and other parties. The NC even lost its public support in many parts of the eastern province except its main base, Akkaraippattu. Due to internal crisis and policy issues, NC lost its one and only parliament membership in 2015 general election.

\subsection{Question of Muslim Leadership}

The charismatic leadership qualities of Ashraff brought him the status of a national and internationally recognised leadership to the Muslim community in Sri Lanka. His parliamentary entry induced a leadership competition between Ashraff and other Muslim ministers and parliamentarians (Yusoff et al., 2017). Ashraff had not been elected nationally, and his party had poor electoral support among the Muslims of the south (out of 
north east). However, Ashraff was accepted as the national political leader of Sri Lankan Muslims among many Muslim representatives because of his distinct Muslim political party and genuine politics for Muslims. Ameerdeen (2006) pointed out that the emergence of SLMC under Ashraff's leadership challenged the established leadership structure among Muslims in Sri Lanka. However, his demise and leadership vacuum prompted to form many political parties and leaders among Muslims, but they hardly adopted the national leadership qualities. When considering their leaders, people expect honesty, reliability, trust worthiness, intelligence, personal character, free of criminal convictions and communication skills specially who can raise the issue in public, parliament and at international forums effectively and efficiently. However, leaders of these Muslim parties evidently failed to qualify on these leadership benchmarks. Similarly, though these leaders proclaimed that they lead Muslim parties based on Islamic principle, they poorly adopted the leadership qualities expressed in Islam, such as trustworthy, loyalty to agreements and concern on public money.

These Muslim leaders also failed to properly respond or united to advocate when Muslims faced serious issues, such as anti-Muslim religious campaigns and Muslims' concerns on political settlement. Similarly, patriotism of leaders of Muslims parties were also criticised by ethnic majorities and the national parties for their stance on national issues. In addition, most leaders of Muslim parties were criticised and suspected for corruptions deals they were involved under their ministries (See: Farook, 2016a). National parties and their leaders openly challenged certain Muslim leaders for their corruption deals, and some were investigated. Similarly, Muslim leaderships were also criticized due to personal matters and ethnical characters as leaders of Muslim parties functioning based on Islamic principles. Therefore, Muslim politics in post-Ashraff era lacked charismatic national leadership that was recognised and accepted nationally and internationally when Ashraff led SLMC. This ultimately questioned the identity and contribution of Muslim leaderships in matters concerned with Muslims and national issues. During peace process, there were debates and arguments among major actors of negotiation in recognizing Muslim leadership as to discuss the Muslims concerns. As a result, earlier peace talks and political settlement process were held without the due recognition and representation of Muslim leadership. With the wider fragmentation of Muslim politics in the recent past, ethnic majorities further questioned the Muslim leadership in many occasions.

\subsection{Question of Muslim Representation}

The electoral victory of SLMC provided an identity to Muslim minority politics in Sri Lanka. Though Muslims were elected under major national or pro-Sinhalese parties and became prominent leaders and influential within and outside the cabinets and governments, they could not express the grievances of Muslim community and function independently. Muslim representatives elected under SLMC were viewed differently or as true or sole representatives of the Muslim community. However, Muslim representatives elected in Muslim parties or elected under major national parties during post-Ashraff era could not sign well and became dummies other parties. In most elections in this era, SLMC and other Muslim parties contested elections under UNP or SLFP or their coalition alliance, like PA, UNF or UPFA. Therefore, they could not symbolically or meaningfully represent the Muslim community although higher number of Muslims were elected to the national parliament and provincial councils representing Muslim parties. Muslims in north-eastern region have a strong feeling and attachment with SLMC and other Muslim parties as their own ethnic parties. Most of them like these parties' own symbols, particularly the tree symbol of SLMC. However, SLMC and other Muslims parties favoured to contest the elections under major national parties during post-Ashraff era which was argued as a strategy to obtain higher Muslim representations, but it challenged the uniqueness of Muslim's symbolic representation. Contesting elections under major national parties clearly indicated the lack of trust of Muslim leaders on the strength of their own party due to the fragmentation and loss of their own identity.

Given the ethno-religious-based symbolic representation, SLMC promoted an identity-based politics to the Muslim community in Sri Lanka. Muslims view that electing from SLMC is an identity for Muslim representatives. However, Muslim parties in post-Ashraff era rarely promoted identity politics by representing the Muslim community in their own parties. SLMC has progressively lost its symbolic representation in the national parliament and other representative bodies. Only one Muslim MP is currently (2018) at the parliament elected under SLMC's tree symbol. This strategy may help these parties make alliance and hold powerful portfolios, but it challenges Muslim representatives to voice for the Muslim community independently. Certain Muslim parties, particularly SLMC, failed to contest the elections in its own symbol but contested under a temporary symbol because of internal party crisis in certain periods, thereby challenging the symbolic and meaningful representation of Muslims.

There were huge oppositions against Muslim political parties for concealing their party symbol for the sake of coalition politics, but Muslim leaders failed to respect civil concerns. Therefore, Muslim parties surrendered to 
the conditions and commands of major pro-Sinhalese parties that limited leaders of these Muslim parties from expressing their opinions and oppositions as well as from acting independently when issues affect the Muslim community. These Muslim representatives supported many policies, acts and laws of major pro-Sinhalese parties in the government though they were seriously affected the rights and interests of the Muslim community.

\subsection{Lack of a Long-Term Policies and Programmes for the Empowerment of Muslim Community}

Anyone can notice another trend of Muslim politics in post-Ashraff era, that is, the most active political parties, including small and ethnic parties, such as Janatha Vumukthi Peramuna (JVP) and Tamil National Alliance (TNA) release their electoral manifestos explaining their policies and programmes if they are elected to the parliament and form the government, even as a coalition party. But, such manifestos lack in Muslim politics. Almost all Muslim parties, including SLMC which has been maintaining a high representation at the national parliament, provincial councils and local government bodies avoid releasing their manifestos in any elections, including national level elections. Siddeek (2015a) questioned how these Muslims parties and leaders would deliver initiatives and implement sustainable development programmes for the empowerment of their community given the lack of credible policies and programmes. Therefore, Muslim voters face challenge to select their representative wisely. Several issues arise for Muslims in the regional and local levels, such as youth unemployment, poor education policies and lack of resources in schools, sky rocketing cost of living, deteriorating standard of living, poverty, land and colonisation problems, civil war-related displacement and resettlement issues, loss of political representation, irrigation problem as well as local economic and industrial development. These issues must be addressed and resolved properly through the electoral and coalition politics and politics of bargaining. However, most of these Muslim parties fail to bring about these issues into their political agendas and political agreements during elections and post-elections coalitions. They only show their keen interests on bargaining power positions and benefits for their families, friends and their inner circles. In the post-civil war context, political parties and leaders are focusing on political settlement process, however, Muslim parties have not clearly expressed their stances or policies on the matters of Muslims' accommodation in the post-war resettlement and development process. Also, they have not clearly proposed any concrete policy or plan for ethnic conflict resolution, particularly of accommodating Muslims within political power-sharing discourse and structure.

\subsection{Lack of Collective Voice for Muslims' Concerns and Grievances}

When Ashraff led SLMC, it was identified as an institution voicing for Muslims and Muslim concerns within and outside of Sri Lanka. After his demise, all Muslim MPs and the Muslim ministers argue that they are voicing for Muslim community. However, when Muslim community faced challenges with regards to their rights and privileges, most of these Muslims leaders kept silent or avoided collectively voice for their community. Muslims expect sound voices from their leaders particularly on the matter of unallocated tsunami housing scheme in Nuraichcholai area in Akkaraippatthu, land issues of Muslim in many districts of the north-eastern region, settlements of ethnic majorities in traditional Muslim areas, and issues with regard to practicing Islamic principles and Muslim cultural identity. However, these Muslim parties and leaders rarely express their collective voice for these issues.

The resettlement of civil war-related displaced Muslims (of northern province in particular) and Muslims affected by the 2004 tsunami, have been challenging issues for Muslim community in the last two decades. The resettlement of northern Muslims who have been living in refugee camps and relocated villages for a quarter century is one of the areas that Muslim politicians failed to voice collectively (See: Yusoff, Sarjoon \& Zain, 2018). When these Muslims were forcefully evicted, the government of that time was seriously fighting with the LTTE in the northern province, thus no plan and policy emerged for the return and permanent resettlement of these Muslims. But, whilst Ashraff was active in politics and in power, he initiated several projects to temporarily resettle these Muslims in relocated villages with basic amenities through his ministries.

With Ashraff's demise, northern Muslims resettlement became the marginalized subject in Muslim politics. However, whilst post-war governments were implementing resettlement schemes at the absence of civil war, SLMC or other Muslim parties or their leaders, except ACMC and its leader, did not propose any comprehensive plan for the permanent resettlement of these Muslims. When initiatives for the resettlement of these Muslims by ACMC leaders received huge criticisms and oppositions from nationalist forces among Sinhalese and from environmentalist groups, SLMC or other Muslim parties and their leaders neither supported ACMC leaders nor the northern Muslims (See: Yusoff et al., 2018).

The Muslim community was severely affected by the 2004 Asian tsunami, devastating their lives, residences and livelihoods. Their resettlement and permanent housing assistance were unsuccessful. Muslims living in the 
coastal belt of Amparai district were highly victimised by the tsunami. Nearly 70 percent out of about 11,000 deaths were Muslims in this district. Most coastal belts of the Amparai district of about $100 \mathrm{~km}$ was seriously devastated. Hundreds of families are still living in temporary shelters, and Muslim parties have not proposed any comprehensive programme to rebuild permanent residences and livelihood facilities for these Muslims, though these parties have many loyalties and supporters in this district. Mrs. Ferial Ashraff, the leader of NUA and then Minister of Housing and Common Amenities facilitated for a permanent housing scheme for the Muslim victims in the Amparai district with the financial support of Saudi government. Under this scheme, nearly 750 houses with other basic amenities were built in Nuraichcholai area in the Akkaraippatthu Divisional Secretariat division. However, at the end of construction, the supreme court ordered to stop issuing these houses to only Muslims but to all ethnic groups. Neither Muslim parties nor their leaders justified or clarified the background of the housing schemes and convinced relevant government authorities to allocate these houses for Muslim victims. For 12 years, these houses are abundant without maintenance and are undistributed to the victims (See Yusoff, Sarjoon, Hussin, 2016; Farook, 2013). This situation shows the lack of unity and collective responsibility of Muslim parties in resolving urgent and basic issues of Muslim community.

Muslims in many parts of the north-eastern region are facing several administrative issues in accessing public services, particularly at district secretariats, district level government departments and divisional administrative units. The domination of Sinhala language as well as Sinhalese bureaucrats and related issues cause several issues in the public administration and public service delivery. In Trincomalee and Amparai, Muslims form majority of the district's population, but the two districts continue to be administered by Sinhalese bureaucrats with the full domination of Sinhala language. The condition is worst in Amparai district in which no Tamil-speaking or Muslim district secretary is appointed out of the 23 appointed from the formation of the district in 1961 (Sarjoon, Yusoff, Hussin, \& Awang, 2015). This condition has prompted Muslims to call for a separate district administration for their area in the form of a new administrative district. In post-Ashraff era, SLMC has been advocating for this proposed district for the last two decades and became the main political demand of the party. However, though SLMC had many occasions, it failed to utilise them to establish the proposed district using its politics of bargaining and coalition making (Yusoff \& Sarjoon, 2016). None of the other Muslim parties supported or advocated the establishment of this proposed administrative district in post-Ashraff era. SLMC also uses this Kalmunai district demand only as an electoral weapon to cheat voters and to gain political patronage in electoral politics (Yusoff \& Sarjoon, 2016).

One of the areas that Muslim political parties failed to collectively express their concerns and present their comprehensive proposal is the electoral and constitutional reform process. Governments in the post-war era attempted to reform the electoral system and to present a political settlement scheme by altering the existing constitution in many ways. Many parliamentary committees and commissions were formed in this regard. Although many leaders and representatives of Muslim parties represented these committees and commissions, their contributions were limited and un-noted. No collective forum existed among these Muslims parties and leaders to voice their community issues and grievances in an organised manner. Few proposals were presented on behalf of Muslims but those were individual parties' proposals which were neither consulted nor discussed with other parties and civil society institutions.

With the end of civil war by defeating LTTE in 2009, Rajapaksa regime easily allowed the predominance of ethno-religious nationalist forces among Sinhalese. These forces reconceptualised the Sinhala-Buddhist hegemony arguing that Sri Lanka is a Sinhalese-Buddhist country in which no room for other ethno-religious groups is allowed on an equal manner. These forces opposed the existence and practice of other religions in the country. Accordingly, they mainly targeted Muslims and Islam in the post-war era by attacking the places of Islamic worships and teaching, such as mosques, madrasas and shrines, and questioning the practice of several Islamic fundamentals, such as halal, Islamic Shariya and Islamic cultural attires. The anti-Muslim sentiment and violence negatively influenced the religious practice of Muslims and their socio-economic and livelihood activities in many ways (See: Yusoff \& Sarjoon, 2017; Sarjoon, Yusoff and Hussin, 2016). Public, critics and researchers pointed out that these anti-Muslim sentiment and violence were politically motivated. However, throughout the post-civil war era, almost all Muslim leaders were with the government and silently supported the inability of government authorities to keep the Muslim community safe from the target of anti-Muslim forces (Farook, 2014). These Muslim leaders rarely voiced for the grievances of Muslims or opposed violent forces. Huge demands and opinions arose among Muslims urging Muslim leaders to withdraw their supports to the regime, but Muslim leaders still supported the regime till they disagree with their refused due shares.

Though Muslim parties and their leaders had many opportunities to materialise or accommodate all Muslim demands, concerns and grievances through their coalition politics, they failed due to their inter-party leadership 
crisis, lack of unity, fragmentation and opportunistic politics among these parties. Rauff (2013) identified the leader of SLMC the major reason for the vulnerable position of Muslims and their continued grievances in post-Ashraff era. He added that Hakeem has also been a powerful member at the cabinet of virtually every successive government after Ashraff. Unfortunately, he never used all politically important opportunities to address Muslims' issues or represent their interests appropriately. Instead, he repeatedly substantiated his ill-equipped leadership in representing his community on all occasions (Rauff, 2013). For other Muslim parties and their leaders, several opportunities existed to put forward Muslim concerns and grievances when they supported governments in making crucial decisions, laws and constitutional amendments or signed for electoral coalition agreements. Unfortunately, they concerned mostly about cabinet portfolios and other powerful positions for them and their party stalwarts.

\subsection{Question of Muslims'Autonomy Concerns in Political Settlement}

Tamils' demands for regional autonomy or self-rule influenced the formation of SLMC and its active ethnic politics. Responding to Tamils' demands, thus Muslims bargained for regional autonomy for the Muslim community living particularly in the north-eastern region (See: Yusoff, Hussin \& Sarjoon, 2014; Sarjoon 2011; Uyangoda, 2010; Mohideen, 2006; Mohideen, 2002). The formation of SLMC in 1986 was a key development in the Muslim mobilisation for regional autonomy (Knoerzer, 1988). Ashraff and SLMC continued to advocate for the Muslim predominant autonomous political unit on a non-contiguous basis if northern and eastern provinces were to be merged as one unit of power-sharing to resolve the ethnic conflict in Sri Lanka.

In post-Ashraff era, the advocacy for Muslim autonomy progressively declined, and almost all Muslim parties (except SLMC to a certain extent) were silent on the matter of Muslim autonomy. Muslim parties never ever collectively advocated and proposed any proposal for autonomy arrangement for Muslims in the power-sharing arrangement. In this era, SLMC or any Muslim party did not show its clear stance on the matter of establishing an autonomous political unit for Muslims as a mechanism to accommodate Muslim concerns in political settlement. These parties were happy with the government decision of sharing central power to provinces. SLMC only reminds about its long-term autonomy demand during election periods. Until the eastern province was merged with the northern province, Muslims had no opportunity or means to control the provincial politics and administration but were controlled by ethnic majorities. However, these Muslim parties failed to use opportunities to control or experience the political autonomy in the Eastern Provincial Council after it was demerged from the northern province and empowered with representative politics.

Particularly, during and after the Eastern Provincial Council elections held in 2008 and 2012, high opportunities for Muslims were available to secure high representation and to control the provincial government. The demerger of the northern and eastern provinces, in fact, permanently paved ways for Muslims in the eastern province to influence the provincial administration and governance. Huge demands emerged from civil society to form Muslim political alliance in two elections, but Muslim parties failed due to leadership crisis and power domination between them. Muslims form the decisive majority in the population of eastern province, thus if all Muslim parties united and contested the elections under a common symbol, then they could have easily controlled the provincial government. In these two elections, SLMC, the major Muslim party that has been advocating for Muslim autonomous unit for nearly three decades, had not taken any positive step to unite all Muslim political parties to contest elections and to control governance and administration of Eastern Provincial Council.

\section{Discussion}

The formation of SLMC and its district form of communal politics strengthened the Muslim politics in different ways. SLMC under Ashraff's leadership opened a new era in Sri Lankan Muslim politics. SLMC rose as the third force in national politics with the capability of influencing central governments. It provided symbolic and meaningful representation to the Muslim community. It articulated the interests and rights of Muslims and spoke against the victimisation and marginalisation of Muslims caused by ethnic politics, ethnic conflict and the peace process. Ashraff's leadership and his new brand of politics challenged the politics of traditional political parties, and earlier Muslim leaders. Ashraff publicly claimed that SLMC has emerged as the 'king-maker' and without its support, the government could not be formed (Farook, 2014). However, his brand of politics and his bold speeches brought him and his politics more critics and opponents. Many Sinhalese leaders within and outside the government criticised the speeches and the demands of Ashraff. Therefore, the influence of Ashraff and SLMC in national politics received huge criticisms and oppositions from ethnic majorities, and they undermined Muslims' district politics in different ways, including making splits and fragmentation within SLMC. Although they were expecting opportunities, the sudden demise of Ashraff easily gave rooms for ethnic majorities, 
political parties and forces representing them to group SLMC loyalties and create leadership competition.

Many SLMC loyalties argued that President Chandrika Kumaratunga exploited the confusion in SLMC to her own advantage by making Ferial Ashraff a minister while leading NUA (Farook, 2014). As Hakeem and Ferial Ashraff were in the same cabinet which was new to SLMC's policy of sole or single leadership, an invisible power struggle brewed between the two wings (Hakeem and Ferial), causing further divisions and much disillusionment among party members. Ferial Ashraff evidently extended her support to PA to form a government when President Kumaratunga met her personally, surprising the other wing of SLMC, after the 2000 general election. The continued electoral success of SLMC in the absence of Ashraff challenged Sinhalese leaders who thought only Ashraff was their threat. They later found that the party's policy was also a threat, thereby leading them to further intervene and make splits within the party. Further splits were promoted for the sake of authoritative positions and cabinet portfolios, particularly during the Rajapaksa regime (2005-2014) in all Muslim parties.

Fragmented and weak positions of Muslim political parties as well as their role in Muslim and national politics automatically raise a question whether Muslim parties should change their political direction and path. To strengthen Muslim politics, many argue that Muslim parties should revise their party structure, constitutions, missions and visions as well as the paths to achieve them. Ali (2013) claimed that Sri Lanka's Muslims are at an unprecedented and ominous crossroads. The community is faced with an existential threat at the hands of an increasingly militant Buddhist majority, whereas the nation's Muslim parliamentarians appear to be more powerless and mute than at any time since 1947. In the face of increasing violence against Muslims' businesses, mosques, madrassas and lives, Ali further argued that Muslim community desperately needs a change of political strategy if they are to live as citizens, equal in status to all their compatriots. That strategy must be devised by an enlightened leadership working in collaboration with the silenced majority (See Ali, 2013). Therefore, the community must change its attitude towards domestic politics as a first step.

Muslims must advocate for citizenship rights that are common to all Sri Lankans rather than promote and advocate for ethno-centric rights and demands. Proposing ethnic and rights-based demands and alternatives would have been possible during ethnic conflict and civil war. However, in a post-war context in which the war was succeeded with the defeat of minority demands and forces, Muslim political parties and community must advocate for the proper implementation of general laws that should ensure the rights of all ethnic groups rather than Muslims demanding for their special rights and specific political autonomous arrangement in political settlement.

In fact, there are debates and arguments among Sinhalese and their politicians questioning the patriotism and promoting and protecting national interests of Muslim leaders because of their intense communal party politics. Therefore, in the post-civil war context, all Muslim leaders must show their patriotism and commitment to safeguard the country's long-protected heritage and image. In the history of Sri Lanka, Muslim leaders are remembered as patriotic leaders. However, during and after the civil war, Muslim leaders who were critics of government decisions that opposed the interests of the Muslim community, or those who advocated the rights of Muslims and minorities were labelled as promoting communal politics and separatist demands. Oppositions and criticisms for communal politics have increased with the defeat of terrorism and the end civil war. As strongest supporters of defeating terrorism in the country, Muslim parties and their leaders have the responsibility of strengthening ethnic reconciliation, ethnic cohesion and national integration in the country.

Muslim community in the country is in a vulnerable position in terms of socio-cultural, economic and political spheres. They face huge challenges to empower or enhance them in all spheres. Despite being a neutral party to the ethnic conflict and civil war, Muslims of the north-eastern region were severely affected by civil war and are vulnerable in the accommodation of post-war development and political settlement. They are the major target of post-war nationalism, religious hatred and violence. Therefore, an uncertain future has been created for Muslim community in Sri Lanka. Muslim leaders and politicians of SLMC and other Muslim parties are responsible for uniting Muslim political forces and actively advocating for concerns, grievances, rights and privileges of Muslim community and their bright political future whilst maintaining harmonious relations with other communities and political forces.

\subsection{Uniting Muslim Parties Under a Common Umbrella}

Alternatively, Muslim politicians must think about unification of Muslim political forces. They can come under one united Muslim front to voice for Muslims and to contest future elections under a common symbol like TNA even if each splinter group wants to keep their party and symbol. Unity may give them more representations which can strengthen the bargaining power of Muslim politics at national, regional and local levels. These 
Muslim parties align with different coalitions in elections, thus they sometimes lose due Muslim representations. They cannot demand much from major parties in certain cases. Contesting elections under a common Muslim front may reduce their dependency on major political parties and enhance their bargaining power even if they want to bargain for portfolios and high-profile positions. However, Siddeek (2015b) argued that obstacles may appear for such a move from elements with vested interest in dividing the Muslims. The success of uniting Muslim parties depends on how they overcome those obstacles. Therefore, Muslim parties should develop a clear vision and objectives for the sake of community and strategies as well as policies and programmes to achieve them.

Uniting Muslim parties may possibly help restore the identity and symbol of parties, and they no longer have to embrace the symbol and policies of other parties for the sake of contesting and winning future elections. This unity can rebuild the trust of Muslim parties which have considerably lost now. It can also clear the bad image the Sinhala leadership may have about SLMC and its splinter groups or other Muslim parties that they can be bought over for portfolios and positions anytime (Siddeek, 2015b).

The responsibility for the prevailing fragmentation and internal crises, including leadership rivalry among Muslim parties is entirely depends on the leaders of such political parties and religious leaders who should guide or provide guidelines for solving community problems. They must take necessary positive roles to unite Muslim political forces under a common platform to ensure renewed brand (identity) of politics and utmost possible Muslim representation, as well as to influence national politics particularly in governance. They must also take a possible initiative to resolve internal crises in terms of regionalism and personalities among Muslim parties. Continuous negligence can further induce fragmentation within all parties.

\subsection{Change within SLMC}

SLMC, as a mother party and major party that receives the highest public mandate, must be reformed and restructured internally to the interest of the Muslim community. Siddeek (2015b) argued that many SLMC activists and Muslims firmly believe that the decision-making process of SLMC must be democratised in respect of appointment of office bearers, including the position of party leaders, selecting candidates for elections and selecting national list MPs. If the change in the process can be made, then it may also pave the way for SLMC splinter group leaders and founder-members, including intellectuals, professionals and academics to come back and unite under one umbrella party and work for the common cause of the Muslim community. This unification may also help expand Muslims' future representation countrywide, particularly in the districts where Muslims form second and third majorities.

Many Muslims commonly believe that certain party activists left SLMC and formed their own parties because they could not resist the leadership as well as their disagreement to the selection of leader and his decisions which were against community wishes and were not in the best interest of the party. Therefore, the leadership contest must also be democratised, and opportunities must be given to other aspirants to contest the position. Ali (2017) argued that SLMC launched its political campaign with the religious slogan 'Allahu Akbar' and resolved to fight for and win the rights of Muslims. Nowhere in its party manifesto the party leaders spelt out what those unique rights are for which they fight for and how many of those mysterious rights have the party won for the community so far. Instead, corruption, nepotism, regionalism and personal animosities have become the bane of this party, and its narrow ethnic image and reckless religious sloganeering have added fuel to the communal fire in the country. Therefore, SLMC must urgently reshape its vision and mission and the ways of achieving them. Similarly, other Muslim parties must also reform their party structures and constitutions allowing additional reforms particularly focusing on decentralising powers and positions within the party to promote democratic and nationalistic ideas.

It is worth noting that the power-structure within the party influenced SLMC's fragmentation and splits in post-Ashraff era. According to Aman, the one and only son of SLMC's founder, Ashraff, the fragmentation of SLMC is a direct result of a seizure of power that took place after the demise of Ashraff and over the course of the following years that gradually evolved into a carefully planned process of consolidation of the same power (Jeyaraj, 2017). Aman further argued that the constitution of SLMC has been doctored on numerous instances in the last 17 years as a preventive measure taken by parties with vested interests to ensure the absolute preservation of the current leadership and the office bearers who are in line with that leadership's political ambitions. Any form of dissent or difference in opinion has resulted in severe persecution or near instant expulsion from the party. This leadership has led to a repetitious lack of confidence in SLMC and to the emergence of new Muslim political entities (Jeyaraj, 2017). Therefore, urgent reform in the power-structure and 
other areas in Muslim parties is a must for making Muslim parties more democratic and to attract the attention of Muslims and other ethnic groups.

'United we stand and divided we fall' is an age-old mantra that was always remembered by Ashraff. Until he led the party, he tried to unite all or avoided divisions within the party loyalties though many confronted with his leadership and autocracy within the party structure and later left the party. However, the mantra is too difficult to put into practice in SLMC and Muslim politics in post-Ashraff era. SLMC and other Muslim parties have their ultimate supporters from the eastern province, thus leaders and the supreme council of these parties must consider the specific concerns and opinions of eastern Muslims in their political transformation.

\section{Conclusion}

In the history of Sri Lanka, Muslims continued to live harmoniously with ethnic majorities, the Sinhalese and the Tamils. Similarly, the politics of traditional Muslims was also viewed as neutral and patriotic. This tradition continued even in the post-independent era. Muslim leaders' politics of pragmatism helped them be aligned with the two major national parties, UNP and SLFP. Therefore, Muslim leaders still managed to contain the hatred towards the community despite the rising chauvinism and sporadic anti-Muslim attacks. But, the intense ethnic conflict and civil war together with extreme ethnic politics of Sinhalese and Tamils induced Muslims to feel the need for their own political force and voice to highlight their grievances and ensure their rights. Thus, a vacuum arose in the Muslim political leadership which was cleverly exploited by late Ashraff who was then running from party to party in search of a platform to start his own party, SLMC in 1986. In subsequent years particularly from 1994, SLMC began to play a decisive role in forming governments. Ashraff and his party voiced grievances of Muslims and advocated for their rights, privileges and due shares in resource allocation and in local development. The distinct brand of Muslim politics of SLMC under Ashraff antagonised the leaders of ethnic majorities, thereby labelling it as an extreme version of ethno-religious politics. They were fed up of yielding to Ashraff's demands, thus exploited the opportunity to suit their own agendas.

The sudden demise of the SLMC founder-leader, Ashraff progressively caused splits and fragmentation not only in SLMC but also in Muslim politics in Sri Lanka. With the fragmentation of SLMC, many Muslim parties were formed, opposing one another. It further allowed for two-polar politics and alliance-making of Muslim parties, but fragmentation in Muslim politics negatively influenced the rights and privileges, representation, identity and socio-economic status of the Muslim community in post-Ashraff era. The fragmentation also challenged the bargaining power of Muslim politics. In post-Ashraff era, particularly in the post-civil war context, Sri Lankan Muslim community went through its worst ever political and leadership crisis which placed the community in a precariously helpless situation. Many local and foreign forces secretly worked against Muslims behind the divisions and fragmentations within the Muslim community and their politics.

All Muslim political parties are now following a policy of supporting Sinhalese leaders and they aim positions and perks rather than focusing on the benefits of their Muslim community. When regimes attempt to undermine the democratic principles and governance in the country, all these Muslim parties give their strong support despite criticisms and oppositions for their acts. Surrendering to major Sinhalese parties and their regimes help Muslim parties and leaders secure their power position but put the Muslim community aside vulnerable to practice and experience their rights and privilege. In the post-civil war context, Muslim community became the highest target of anti-minority sentiments and violence imposed by radical religious cum nationalist forces among Sinhalese. However, Muslim leaderships or parties hardly expressed their collective voice for the Muslim community.

Development or change occur in politics of other communities at national and community levels, thus Muslim leaders and community should also think about national change in their brand of politics in a plural societal context. Muslim political parties and forces must unite to collectively advocate for the interests and rights of the Muslim community without challenging the national interests and territorial integrity of the country. Politics for self-rule and autonomy or even the identity-based politics of ethnic minorities is a failed history in Sri Lanka. Therefore, Muslim leaders must transform their ethno-religious identity-based politics into a national level brand of politics, considering the new development occurring among ethnic majorities in the country and by leaning on lessons from the recent history.

\section{References}

Ali, A. (2013). Sri Lanka's Muslims: the end of the road. Colombo Telegraph. Retrieved from https://www.colombotelegraph.com/index.php/sri-lankas-muslims-the-end-of-the-road/

Ali, A. (2017). Ineffectual leadership, corrupt politics and persisting problems in Muslims Sri Lanka. Colombo 
Telegraph.

Retrieved

from

https:/www.colombotelegraph.com/index.php/ineffectual-leadership-corrupt-politics-persisting-problems-i n-muslim-sri-lanka/

Ameerdeen, V. (2006). Ethnic politics of Muslims in Sri Lanka. Kandy. Center for Minority Studies.

Balachandran, P. K. (2016). Sri Lanka Muslim Congress funder rebels against party. The New Indian Express. 20 March.

Retrieved

from

http://www.newindianexpress.com/world/Sri-Lanka-Muslim-Congress-Founder-Rebels-Against-Party/2016 /03/20/article3337517.ece

Bustø, M. (2007). Politics of a second largest minority or the fragmentation of Sri Lankan Muslim politics after year 2000. (Unpublished master thesis). Institute for Political Science, University of Oslo, Oslo, Norway.

Cader, M. L. A. (1999). The tenth general election of Sri Lanka - the Muslim perspective. Peradeniya: Sri Lanka Political Research Society.

Daily Mirror. (2014). Rishad's party splits; Hisbullah remains with MR. Daily Mirror. 23 December. Retrieved from http://www.dailymirror.lk/59621/rishad-s-party-splits-hizbullah-remains-with-mr

Farook, L. (2013). Sufferings of Muslim tsunami victims. nine years later today. The Colombo Telegraph. Retrieved

from https://www.colombotelegraph.com/index.php/sufferings-of-muslim-tsunami-victims-nine-years-later-today

Farook, L. (2014). Sri Lanka: SLMC-liability on the Muslim community-time to dissolve and stop represent Muslims. Sri Lanka Guardian. Retrieved from http://www.srilankaguardian.org/2014/12/sri-lanka-slmc-liability-on-muslim.html

Farook, L. (2016). Political and religious leadership crisis of Sri Lankan minority. Retrieved from http://www.dailymirror.lk/114191/Political-and-religious-leadership-crisis-of-a-Sri-Lankan-minority

Farook, L. (2016). Where is Muslim leadership? The Sunday Observer. 21 February. Retrieved from http://www.sundayobserver.lk/2016/02/21/spe-tho-01.asp

Gunatilleke, N. (2004). Unity, peace and development our goals - Democratic Unity Alliance. Daily News. 17 June. Retrieved

from https:/web.archive.org/web/20041211172605/http://www.dailynews.lk/2004/06/17/pol06.html

Jeyaraj, D. B. S. (2004). Hakeem fight last-ditch battle in Amparai. The Sunday Leader. $29^{\text {th }}$ February. Retrieved from http://www.thesundayleader.lk/archive/20040229/issues-more.htm

Jeyaraj, D. B. S. (2012). Segu Dawood saga: another split in the Muslim Congress?. Retrieved from http://dbsjeyaraj.com/dbsj/archives/9912

Jeyaraj, D. B. S. (2016). Remembering M.H.M.Ashraff the legendary leader of the Muslim Congress on his $16^{\text {th }}$ death anniversary. Retrieved from http://dbsjeyaraj.com/dbsj/archives/43109

Jeyaraj, D. B. S. (2017). Muslim Congress founder's son Aman Ashraff speaks out against SLMC. Daily Mirror. 09 December. Retrieved from http:/www.dailymirror.lk/article/Muslim-Congress-Founder-s-Son-Aman-Ashraff-Speaks-Out-Against-SL MC-141889.html

Knoerzer, S. (1998). Transformation of Muslim political identity. In M. Thiruckelvam, \& C. S. Dattathreya (Eds.), Culture and politics of identity in Sri Lanka (pp. 136-167). Colombo: International Center for Ethnic Studies.

McGilvray, D. B., \& Raheem, M. (2007). Muslim perspectives on the Sri Lankan conflict. Washington D.C: East-West Center.

Mohideen, M. I. M. (2002). The Need for power-sharing arrangements for the Muslims in the north-eastern Sri Lanka. Colombo: (author's publication).

Mohideen, M. I. M. (2006). Sri Lanka peace process and the Muslim question. In R. Rupesinghe (Ed.), Negotiation peace in Sri Lanka (Part Two) (pp. 305-329). Colombo: Foundation for Co-Existence.

Rauff, S. A. (2013). Sri Lanka Muslim Congress: a failed leadership of hapless community. Colombo Telegraph. Retrieved from https://www.colombotelegraph.com/index.php/sri-lanka-muslim-congress-a-failed-leadership-of-a-hapless-c ommunity/ 
Razak, A. (2016). Crisis in Muslim politics. Nation. Retrieved from http://nation.lk/online/2016/01/23/crises-in-muslim-politics.html

Sarjoon, A. (2001). The leadership of M.H.M.Ashraff in the Muslim politics of Sri Lanka: a critical analysis. (Unpublished bachelor dissertation). South Eastern University of Sri Lanka, Oluvil, Sri Lanka.

Sarjoon, A. (2011). The changing dynamics of minority rights discourse in eastern Sri Lanka: a study of Muslim demand for territorial autonomy. (Unpublished M.Phil thesis). University of Colombo, Colombo, Sri Lanka.

Sarjoon, A., Yusoff, M. A., \& Hussin, N. (2016). Anti-Muslim sentiments and violence: a major threat to ethnic reconciliation and ethnic harmony in post-war Sri Lanka. Religions, 7(10), 125. https://doi.org/10.3390/rel7100125

Sarjoon, A., Yusoff, M. A., Hussin, N., \& Awang, A. (2015). The demand for an administrative district for the coastal belt of Amparai district in Sri Lanka: an assessment of its root causes. Mediterranean Journal of Social Sciences, 6(4S3), 434-443. https://doi.org/10.5901/mjss.2015.v6n4s3p434

Siddeek, M. Y. M. (2015a). Ugly Muslim politics. Colombo Telegraph. Retrieved from https://www.colombotelegraph.com/index.php/ugly-muslim-politics/

Siddeek, M. Y. M. (2015b). Devastating defeat for Sri Lanka Muslim Congress. Colombo Telegraph. Retrieved from https:/www.colombotelegraph.com/index.php/devastating-defeat-for-sri-lanka-muslim-congress/

TamilNet. (2004). SLMC suspends three MPs over opposition to Hakeem. TamilNet. $19^{\text {th }}$ May. Retrieved from http://www.tamilnet.com/art.html?catid=13\&artid=12041

Uyangoda, J. (2010). Politics of political reform: a key theme in the contemporary conflict. In S. Bastian, S. Kottegoda, C. Urjuela, \& J.Uyangoda. (Eds.), Power and politics in the shadow of Sri Lanka's armed conflict (pp. 29-78). Colombo: SIDA.

Yusoff, M. A., \& Sarjoon, A. (2016). Ethnic politics and the survival of minorities' demands in Sri Lanka: a historical review of the political advocacy process of Kalmunai administrative district demand. Academic Journal of Interdisciplinary Studies, 5(3), 61-73. https://doi.org/10.5901/ajis.2016.v5n3p61

Yusoff, M. A., \& Sarjoon, A. (2017). Anti-Halal and anti-animal slaughtering campaigns and their impact in post-war Sri Lanka. Religions, 8(4), 46. https://doi.org/10.3390/rel8040046

Yusoff, M. A., Hussin, N., \& Sarjoon, A. (2014). Muslims demand for territorial autonomy in the eastern Sri Lanka: An analysis of its origin, accommodation and the present stance. Asian Social Science, 10(15), 76-88. https://doi.org/10.5539/ass.v10n15p76

Yusoff, M. A., Sarjoon, A., \& Hassan, M. A. (2016). An analysis of the development impact of establishing Kalmunai administrative district in Sri Lanka. Sustainable Development, 9(1), 164-176. https://doi.org/10.5539/jsd.v9n1p164

Yusoff, M. A., Sarjoon, A., \& Zain, Z. M. (2018). Resettlement of northern Muslims: a challenge for sustainable post-war development and reconciliation in Sri Lanka. Social Sciences, 7, 106. https://doi.org/10.3390/socsci7070106

Yusoff, M. A., Sarjoon, A., Hussin, N., \& Ahmed, A. (2017). Analyzing the contributions of Sri Lanka Muslim Congress and its founder-leader to Muslim community and politics. Social Sciences, 6(4), 120. https://doi.org/10.3390/socsci6040120

\section{Copyrights}

Copyright for this article is retained by the author(s), with first publication rights granted to the journal.

This is an open-access article distributed under the terms and conditions of the Creative Commons Attribution license (http://creativecommons.org/licenses/by/4.0/). 